\title{
Explorer of the deep
}

\section{Jacques Cousteau: The Sea King \\ by Brad Matsen \\ Pantheon: 2009. 336 pp. $\$ 27.95$}

Pioneer of marine conservation Jacques-Yves Cousteau - affectionately dubbed JYC, Captain Cousteau, Captain Planet, the Sea King or simply 'the man with the red cap' - is known worldwide for his exploration of the ocean and his success in popularizing its wonders. Yet those who mistrust his fame often question whether his work was as valuable scientifically as he made out.

Cousteau's colourful life has already inspired several works in French and English, including two personal accounts by members of the crew of the RV Calypso, the legendary ship he used as an expedition vessel and research lab from 1950 until his death in 1997. The latest contribution is The Sea King by Brad Matsen, who has been writing books and documentary scripts about the sea and deep ocean for 30 years. Matsen pays only limited regard to Cousteau's scientific achievements, although he claims to go further than all previous biographies of the explorer, telling the complete story of his life and throwing new light on a complex personality. In this, at least, he largely succeeds.

The book contains many little-known details of events from Cousteau's life obtained from interviews with relatives and collaborators. Matsen accurately describes the creation of the aqualung, the first free-swimming underwater breathing equipment that Cousteau developed with the engineer Emile Gagnan in 1943, as well as his other technological contributions to underwater exploration. He describes many of the Calypso's expeditions, dwelling at some length on the people who played a prominent part in them alongside Cousteau. These include Philippe Tailliez and Frédéric Dumas, known with Cousteau as the three Mousquemers, or musketeers of the sea; his first wife and business partner Simone Melchior, also nicknamed La Bergère, or the shepherdess; his two sons; and other long-serving members of the Calypso crew.

Cousteau's story is mostly one of groundbreaking adventure, but Matsen is not afraid to delve into the dark side of his life and character, something previous biographers have been reluctant to do. There is plenty to chew on: his sometimes difficult relationships with his sons, his persistent financial problems, the fate of the Calypso (currently being refurbished in Brittany), the controversial role of his second wife Francine and the death of his son Philippe in a seaplane accident in 1979. He also chronicles the sad death from cancer of La Bergère, who was the soul of the Calypso and had a key role in many of its voyages.

One drawback of the book is that whereas Matsen covers most of the Calypso's expeditions in detail, inexplicably he devotes only two lines to Cousteau's Antarctic trip in 1972-73. According to previous accounts, the Calypso's crew considered this journey their most remarkable. It was one of the last on which Cousteau was personally present, directing operations with his wife Simone. It was also the most risky: the Calypso's wooden hull was not built for navigation in pack ice. The films that the crew shot of the Antarctic environment were seen by millions and the expedition was probably decisive in Cousteau's involvement in the Protocol on Environmental Protection to the Antarctic Treaty of 1991, which designated Antarctica as a nature reserve for 50 years.

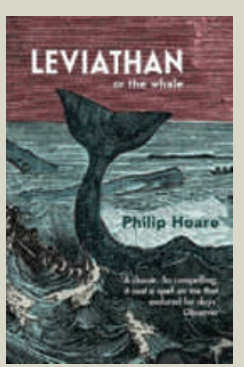

\section{Leviathan: Or, the Whale}

by Philip Hoare (Fourth Estate, $€ 8.99$ )

Philip Hoare explores the whale and its significance to humans. Meandering through biology, economics, cultural history and his own obsession with the creatures, he describes everything from the possibility of us surviving in their bellies to gritty details about the nineteenth-century whale trade, concluding that much about the whale remains mysterious.

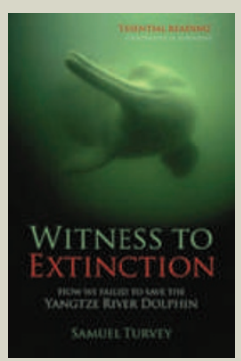

Witness to Extinction: How We Failed to Save the Yangtze River Dolphin by Samuel Turvey (Oxford Univ. Press, £8.99) Naturalist Samuel Turvey gives a personal account of the 2006 survey that determined the baiji dolphin was extinct. Describing it as a "godawful, soul-destroying experience", he touches on the significance of the baiji's extinction, local myths of its origin, the failed preservation project and other cetaceans such as the endangered vaquita. 
of his work. He could have done more to highlight them. Most of Cousteau's first expeditions on the Calypso were predominantly scientific, and during the first years of his ownership she was the only French oceanographic ship, offering scientists the possibility of making direct observations down to 300 metres for the first time. Sponsored by the French National Centre of Scientific Research, his expeditions to the Mediterranean, the Red Sea and the Atlantic resulted in numerous publications, most of which are collected in the 11 volumes of the series Résultats Scientifiques des Campagnes de la Calypso, which contain important contributions to marine science. Cousteau was foremost an explorer, but his contribution to science was immense.

Jean Vacelet is a marine biologist at the Centre d'Océanologie de Marseille, Université de la Méditerranée, Marseille, France. He took part in several of the Calypso's scientific expeditions. e-mail: jean.vacelet@univmed.fr

\section{Darwin's puppy love}

\author{
Darwin's Dogs: How Darwin's Pets Helped \\ Form a World-Changing Theory of Evolution \\ by Emma Townshend \\ Frances Lincoln: 2009. 144 pp. \\ $\$ 14.95, £ 8.99$
}

and his letters home to his three older sisters are packed with affectionate banter about the animals. Writing of how much he missed his family's dogs, and in turn being told by his sisters how much the dogs missed him, was a face-saving way for a young man to admit his

Even the most ardent fan of Charles Darwin might be feeling weary as his anniversary year draws to a close. Publishers have seemingly explored every corner of Darwin's life: his youth, his marriage, his attitudes to slavery and religion. Emma Townshend adds a fascinating angle - Darwin's love of dogs. Dogs were Darwin's constant companions from boyhood to old age. They were also the animals closest to hand when he explored the implications of his theories. It is surely not coincidental that Darwin's credo was "it's dogged as does it".

In Darwin's Dogs, Townshend adds little new to the Darwin biography. Yet her close reading of his correspondence, filtered to references to the family's dogs, produces a warmer, more intimate portrait than others so far. She plausibly claims that, aside from his years at boarding school and on the aptly named ship HMS Beagle, Darwin spent every day of his life in the company of dogs.

Motherless at eight years of age and packed off to boarding school, the young Darwin had, by his own admission, a "passion" for dogs,

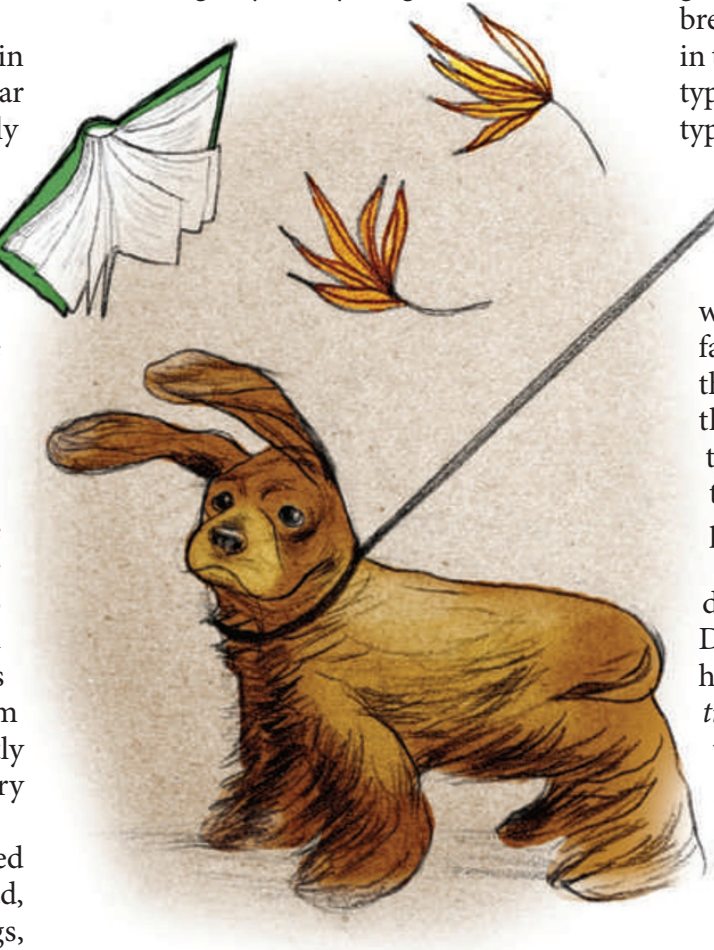

homesickness and exchange affection without embarrassment.

On his first morning back home after five years on the Beagle, Darwin went straight to the stables to see how his old "savage" dog, "averse to all strangers", would react to his return. Would the dog treat Darwin peaceably as befitted someone familiar, or would it growl at him showing that it had forgotten its master? As Darwin later recalled in The Descent of Man, the dog, "obeyed me, exactly as if I had parted with him only half an hour before. A train of old associations, dormant during five years, had thus been instantaneously awakened in his mind."

As Darwin's thoughts turned to 'transmutation' of species, the actions of dog breeders intrigued him. By carefully selecting those animals best suited to their purposes to form the parents of the next generation, breeders offered Darwin a metaphor - artificial selection - from which he could derive his great guiding principle of natural selection. Dog breeders were especially important to Darwin in trying to understand the sources of phenotypic variability and how varieties bred true to type - questions that were resolved long after Darwin's death.

The other major issue with which Darwin grappled on his return to the United Kingdom was that of finding a wife. There too, canine thoughts were never far from his mind. When he listed for himself the pros and cons of a married life, he noted the companionship of a wife to be "better than a dog, anyhow". In Townshend's narrative, we can see in this comment affectionate praise rather than insult.

On the Origin of Species opens with a discussion of domesticated animals. When Darwin came to his magnum opus on humankind, The Descent of Man, and Selection in Relation to Sex, dogs again have centre stage. Dogs, for Darwin, know happiness and sadness, grumpiness, kindness and loyalty. They understand language - Darwin pressed his neighbour, Sir John Lubbock, into testing the latter's dog's vocabulary - and they have a sense of humour. The

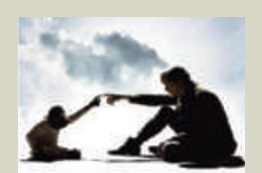
C REA T IO N
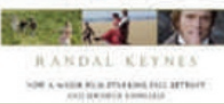

Creation: The True Story of Charles Darwin

by Randal Keynes (John Murray, £7.99)

Originally titled Annie's Box, Randal Keynes's renamed

and re-released book Creation focuses on Charles

Darwin's relationship with his daughter Annie and how her death subsequently affected his research. "Keynes weaves a rich tapestry that gives the reader a sense of the attitudes and assumptions of the Darwin family and their class," explained Bruce Weber in a review of the hardback edition of Annie's Box (Nature 411, 739-740; 2001).

\section{Strange Fruit: Why Both Sides Are Wrong in the Race Debate}

by Kenan Malik (Oneworld, E10.99)

The subject of race is often controversial but, Kenan Malik argues, we shouldn't avoid thinking about it. He attempts to describe what race is and is not, from a biological and cultural perspective, covering modern disputes such as the US approval of a drug for African Americans with heart disease. He also looks at historical views on race and its treatment today. 